\title{
ANALISIS PENENTUAN RAFAKSI DAN PENGARUHNYA TERHADAP PILIHAN SALURAN PEMASARAN PETANI UBI KAYU DI KABUPATEN LAMPUNG TENGAH
}

\author{
Kusmaria'), Ratna Winandi Asmarantaka $^{2)}$, dan Harianto ${ }^{2)}$ \\ ${ }^{1)}$ Program Magister Sains Agribisnis, Fakultas Ekonomi dan Manajemen, \\ Institut Pertanian Bogor \\ ${ }^{2)}$ Departemen Agribisnis, Fakultas Ekonomi dan Manajemen, Institut Pertanian Bogor \\ 1)ndukncus@gmail.com
}

\begin{abstract}
Cassava becomes an important commodity in Indonesia because Indonesia is one of the major producer of cassava in the world. Besides exporting cassava, in fact Indonesia also imported cassava in large quantities. Altough the price of cassava was increasing in Lampung but the production and harvested area were decreasing, moreover factory and trader also set rafaksi on cassavas sold by farmers. Rafaksi is a penalties quantity to assess the quality of cassava farmers. Cassava marketing channels play role in determining the price and rafaksi that received by farmers. The aims of this research are (1) to analyze mechanism of determining rafaksi (2) to analyze price received by farmers' after obtained rafaksi (3) analyze influence rafaksi to choice of marketing channels cassava farmers in Central Lampung Regency. Primary data were collected rendomly from 74 respondents. Data were analyzed by describe, correlation and binary logistic regression. The results showed that in the perception of farmers, determination of cassava rafaksi determined by several criteria such as the age of harvest, varieties, aci levels and the amount of dirt but not obtained a measure to ensure that criteria and only use the visual observation. The results of correlation analysis showed that there was no statistically significant connection between harvest time and the varieties of cassava with rafaksi of cassava which received by farmers. The result of binary logistic regression analysis showed that rafaksi loan significantly affected the choice of marketing channels.
\end{abstract}

Keyword(s): cassava, rafaksi, choice of marketing channels

\section{ABSTRAK}

Ubi kayu menjadi komoditas penting di Indonesia mengingat Indonesia merupakan salah satu produsen utama ubi kayu di dunia. Selain mengekspor ubi kayu, kenyataanya Indonesia juga mengimpor ubi kayu dalam jumlah yang besar. Meskipun harga ubi kayu yang meningkat di Provinsi Lampung tetapi produksi dan luas areal panen ubi kayu justru menurun, mengingat pabrik dan pedagang juga menetapkan rafaksi pada hasil panen yang dijual petani. Rafaksi merupakan potongan berat atau penalti kuantitas untuk menilai kualitas ubi kayu petani. Saluran pemasaran ubi kayu berperan dalam menentukan harga dan rafaksi yang diterima oleh petani. Tujuan penelitian ini adalah (1) menganalisis penentuan rafaksi ubi kayu (2) harga ubi kayu yang diterima petani setelah adanya rafaksi (3) menganalisis pengaruh rafaksi pada pilihan saluran pemasaran petani ubi kayu di Kabupaten Lampung Tengah. Data primer diperoleh dari 74 responden yang ditentukan secara random. Data dianalisis dengan analisis deskriptif, korelasi dan regresi logistik biner. Hasil penelitian menunjukkan bahwa menurut persepsi petani, penentuan rafaksi ubi kayu ditentukan melalui beberapa kriteria seperti usia panen, varietas, kadar aci dan banyaknya kotoran namun tidak diperoleh alat ukur untuk memastikan kriteria tersebut dan hanya menggunkan pengamatan secara visual. Analisis korelasi menunjukkan 
bahwa tidak terdapat hubungan yang nyata antara usia panen dan varietas ubi kayu dengan rafaksi ubi kayu yang diterima petani. Analisis regresi logistik biner menunjukkan bahwa terdapat pengaruh yang nyata antara rafaksi dengan pilihan saluran pemasaran petani ubi kayu.

Kata Kunci: ubi kayu, rafaksi, pilihan saluran pemasaran

\section{PENDAHULUAN}

Ubi kayu merupakan tanaman lokal daerah tropis yang merupakan sumber pangan alternatif dengan kandungan gizi relatif sama dengan beras atau gandum. Ubi kayu berperan cukup besar dalam mencukupi pangan nasional, bahan pakan (ransum) ternak dan bahan baku berbagai industri seperti tekstil, kertas, perekat dan farmasi. Beberapa negara bahkan telah mengembangkan ubi kayu sebagai sumber bahan bakar energi alternatif (biofuel).

Indonesia menjadi produsen utama ubi kayu di dunia dengan produksi mencapai 23 juta ton pada tahun 2014 dan produktivitas mencapai 23.36 ton/ha (BPS, 2016). Bersama Negara-negara lain seperti Nigeria (produksi 54 juta ton), Kongo (produksi 15 juta ton), Brazil (produksi 23 juta ton), Thailand (produksi 30 juta ton) dan menguasai 95 persen luas panen (FAO, 2016) dengan jenis produk ubi kayu yang diekspor ke luar negeri adalah gaplek dan pati ubi kayu (Saliem dan Sri, 2011). Selain menjadi pengekspor, pada kenyataannya Indonesia juga mengimpor ubi kayu dalam bentuk pati ubi kayu dengan Negara pengimpor utama pada tahun 2015 adalah Thailand dan Vietnam (Kementan, 2016). Konsumsi ubi kayu di Indonesia masih cukup tinggi, yaitu 24.044.000 ton pada tahun 2011 dan angka ini terus meningkat setiap tahunnya (Pusdatin, 2012).
Sementara itu produksi ubi kayu Indonesia cukup fluktuatif, mengalami peningkatan dan penurunan selama lima tahun terakhir, bahkan tahun 2013, 2014 dan 2015 produksi ubi kayu Indonesia terus mengalami penurunan (BPS, 2016). Hal ini tentu mengancam ketersediaan ubi kayu di dalam negeri.

Provinsi Lampung merupakan pengahasil ubi kayu utama di Indonesia yang menjadi andalan pemasok ubi kayu nasional dan ekspor. Dari lima provinsi penghasil utama ubi kayu yaitu, Jawa Timur, Jawa Barat, Jawa Tengah dan Sumatra Utara, Lampung memiliki luas panen dan produksi ubi kayu terbesar (BPS, 2016). Sebagian besar ubi kayu di Lampung diolah menjadi tepung tapioka dengan pengguna utama produk ubi kayu segar adalah industri tapioka. Zakaria (2000) dan Sugino et al (2009) menyebutkan bahwa struktur pasar ubi kayu di tingkat pabrik dan tapioka di Lampung memiliki struktur yang cenderung oligopsoni dengan monopsony power yang lemah. Kondisi pasar yang demikian menyebabkan pabrik ubi kayu mempunyai kelebihan dalam price control dan menetukan harga.

Selama sepuluh tahun terkahir dari tahun 2003 sampai 2013, harga ubi kayu di Lampung meningkat dari Rp 306/kg menjadi Rp 1.001/kg (Dinas Pertanian Provinsi Lampung, 2014) namun ironisnya dalam lima tahun terakhir 
produksi dan luas lahan ubi kayu di Lampung justru menurun (BPS, 2016). Hal ini menunjukkan bahwa harga ubi kayu belum mampu menjadi insentif bagi petani untuk meningkatkan produksinya atau beralih pada komoditas lain yang dianggap lebih menguntungkan.

Harga yang diterima petani masih tergolong rendah bila mempertimbangkan adanya rafaksi kuantitas yang nilainya cukup besar pada hasil panen yang dijual petani sehingga membuat sistem pemasaran ubi kayu tidak efisien. Berdasarkan Kamus Besar Bahasa Indonesia, rafaksi berarti pemotongan (pengurangan) terhadap harga barang yang diserahkan karena mutunya lebih rendah daripada, namun pada ubi kayu merupakan pemotongan terhadap berat barang. Sehingga pada ubi kayu rafaksi merupakan sistem potongan berat atau penalti kuantitas untuk menilai kualitas ubi kayu petani. Rafaksi menjadi loss (kerugian) yang menyebabkan berkurangnya berat timbangan hasil panen ubi kayu petani yang dijual. Akiyama dan Akihiko (1996) menyebutkan bahwa dalam penentuan rafaksi ubi kayu di Lampung, petani tidak diizinkan untuk melihat proses penentuannya, seperti kadar aci dan kemurnian ubi, termsuk juga proses penimbangan.

Sagala (2011) menyebutkan bahwa pabrik melihat kualitas ubi kayu dari kadar aci ubi kayu, jenis varietas ubi kayu, usia panen dan banyaknya kotoran atau materi lain yang terbawa pada saat panen ubi kayu. Permasalahannya adalah selama ini petani tidak memiliki pengetahuan yang baik mengenai penentuan rafaksi oleh pabrik atau pedagang. Rafaksi sangat subyektif ketika petani tidak dapat menduga nilai rafaksi karena penentuan rafaksi sebaiknya menjadi kesepakatan kedua belah pihak dan kedua belah pihak memiliki pengatahuan yang sama tentang cara penentuannya. Jika hal ini tidak dilakukan secara transparan, dikhawatirkan petani ubi kayu terus merasa dirugikan seperti pada penentuan rendemen petani tebu oleh pabrik yang juga dianggap merugikan petani.

Keputusan memilih saluran pemasaran merupakan keputusan penting dalam manajemen pemasaran (Kotler 1997). Lebih lanjut Kotler dan Keller (2009) menyebutkan bahwa saluran yang dipilih mempengaruhi keputusan pemasaran lainnya, seperti keputusan terhadap harga. Pada ubi kayu saluran pemasaran tidak hanya berperan terhadap harga yang diterima tetapi juga terhadap rafaksi yang diperoleh petani. Chirwa (2009) menyatakan bahwa setiap saluran pemasaran menawarkan pilihan harga yang berbeda dan pelayanan penjualan yang berbeda pula, yang menentukan petani dalam memilih saluran pemasaran. Penelitian ini bertujuan untuk menganalisis mekanisme penentuan rafaksi, harga ubi kayu yang diterima petani setelah adanya rafaksi dan pengaruh rafaksi terhadap pilihan saluran pemasaran yang digunakan oleh petani ubi kayu, dan di Kabupaten Lampung Tengah.

\section{METODE PENELITIAN}

Penelitian ini dilakukan di Kabupaten Lampung Tengah. Pemilihan lokasi dilakukan dengan sengaja 
(purposive) dengan pertimbangan bahwa Kabupaten Lampung Tengah merupakan sentra produksi ubi kayu di Lampung. Kemudian dipilih kecamatan yang memiliki produksi dan luas lahan terbesar yaitu Kecamatan Bandar Mataram, selanjutnya dipilih Desa Mataram Udik, Desa Terbanggi Ilir dan Desa Mataram Jaya sebagai lokasi pengambilan sampel. Pelaksanaan penelitian dilakukan bulan Maret sampai Juni 2015.

Jenis data yang digunakan adalah data primer berupa data cross section yang diperoleh melalui wawancara langsung dengan responden ubikayu menggunakan kuisioner. Data sekunder diperoleh dari Badan Pusat Statistik, Dinas Pertanian Tanaman Pangan dan Hortikultura Provinsi Lampung, Balai Penyuluhan Partanian Kecamatan Bandar Mataram, dan berbagi tesis, disertasi, serta jurnal yang relevan dengan penelitian. Metode pengambilan sampel dilakukan dengan cara simple random sampling, dengan jumlah total responden adalah 74 responden.

Pada penelitian ini informasi kualitas ubi kayu hanya melalui persepsi petani dan tidak menghimpun informasi dari pabrik atau pedagang karena sulitnya akses memperoleh data. Mekanisme penentuan rafaksi akan dijawab melalui analisis deskriptif. Selain itu untuk mempertajam dalam pendeskripsian, dilakukan analisis korelasi untuk melihat hubungan antara varietas ubi kayu dengan rafaksi dan usia panen dengan rafaksi. Perhitungan harga yang diterima petani setelah adanya rafaksi menggunakan rumus:
Harga diterima $=$

harga sebelum rafaksi $\times((100 \%-$ rafraksi $) \times$ berat total $)$ berat total

dimana :

Rafaksi $=$ persen $(\%)$

Analisis regresi logistik biner digunakan untuk melihat pengaruh rafaksi terhadap pilihan saluran pemasaran karena variabel dependen yang dihadapi adalah variabel kategorik yang berjumlah dua. Adapun pilihan saluran pemasaran yang dihadapi oleh petani ubi kayu meliputi saluran pemasaran melalui pabrik dan lembaga lain selain pabrik. Selain itu dimasukkan juga faktor-faktor lain yang juga dianggap mempengaruhi petani dalam memilih saluran pemasaran. Persamaan yang dibentuk adalah sebagai berikut :

$$
\begin{aligned}
g(x)= & \beta_{0}+\beta_{1} X_{1}+\beta_{2} X_{2}+\beta_{3} X_{3}+ \\
& \beta_{4} X_{4}+\beta_{5} X_{5}+\beta_{6} X_{6}+\beta_{7} X_{7}
\end{aligned}
$$

Keterangan :

$\mathrm{g}(\mathrm{x})=$ saluran pemasaran, 1 untuk saluran pemasaran pabrik dan 0 untuk saluran lembaga pemasaran selain pabrik.

$\beta=$ konstanta

$\mathrm{X}_{1} \quad=$ Harga jual $(\mathrm{Rp} / \mathrm{kg})$

$\mathrm{X}_{2} \quad=$ Jumlah hasil panen $(\mathrm{Kg})$

$\mathrm{X}_{3}=$ Jarak ladang ke pembeli $(\mathrm{km})$

$\mathrm{X}_{4}=$ Lama pendidikan (Tahun)

$\mathrm{X}_{5}=$ Rafaksi (persen)

$\mathrm{X}_{6}=$ Usia panen (bulan)

$\mathrm{X}_{7}=$ Ada pinjaman modal (dummy, $1=$ ya, $0=$ tidak $)$

\section{HASIL DAN PEMBAHASAN} Karakteristik Responden Petani Ubi Kayu

Rata-rata responden memiliki usia antara 15 - 64 tahun yang menunjukkan bahwa responden berada pada usia produktif. Sebagian besar responden memiliki tingkat pendidikan sekolah dasar yang menunjukkan bahwa tingkat 
pendidikan petani ubi kayu masih rendah. Tingkat pendidikan akan berpengaruh pada respon inovasi teknologi serta penguasaan informasi.

Selain tingkat pendidikan, pengalaman juga memiliki pengaruh, pengalaman yang lebih banyak dan lebih lama mengusahakan ubi kayu diharapkan memberikan tambahan pengetahuan dan informasi mengenai pengusahaan ubi kayu yang lebih baik daripada yang berpengalaman lebih sedikit. Rata-rata pengalaman bertani responden antara 10 - 20 tahun. Rata-rata responden memiliki jumlah tanggungan keluarga antara 4-6 orang. Pada petani kecil jumlah tanggungan keluarga menunjukkan ketersediaan tenaga kerja dalam keluarga dan juga banyaknya alokasi anggaran

Tabel 1. Karakteristik Petani Ubi Kayu di Kabupaten Lampung Tengah Tahun 2015

\begin{tabular}{|c|c|c|c|}
\hline No & Karakteristik Responden & Jumlah (jiwa) & Persentase (\%) \\
\hline \multirow[t]{4}{*}{1.} & Berdasarkan Usia (tahun) & & \\
\hline & a. $<15$ & 0 & 0,00 \\
\hline & b. $15-64$ & 69 & 93,24 \\
\hline & c. $>64$ & 5 & 6,75 \\
\hline \multirow[t]{6}{*}{2.} & Berdasarkan Pendidikan & & \\
\hline & a. Tidak Sekolah ( & 4 & 5,40 \\
\hline & b. SD & 39 & 52,71 \\
\hline & c. SMP & 11 & 14,86 \\
\hline & d. SMA/SMK & 19 & 25,67 \\
\hline & e. S1 & 1 & 1,35 \\
\hline \multirow[t]{6}{*}{3.} & Berdasarkan Bertani (tahun) & & \\
\hline & a. $<10$ & 7 & 9,45 \\
\hline & b. $10-20$ & 38 & 51,35 \\
\hline & c. $21-30$ & 17 & 22,97 \\
\hline & d. $31-40$ & 7 & 9,45 \\
\hline & e. $>40$ & 5 & 6,75 \\
\hline \multirow[t]{4}{*}{4} & Jumlah Tanggungan Keluarga (Orang) & & \\
\hline & a. $\leq 3$ & 27 & 36,48 \\
\hline & b. $4-6$ & 44 & 59,45 \\
\hline & c. $\geq 7$ & 3 & 4,05 \\
\hline \multirow[t]{3}{*}{5} & Pekerjaan Utama & & \\
\hline & a. Petani & 64 & 86,48 \\
\hline & b. Bukan Petani & 10 & 13,51 \\
\hline \multirow[t]{4}{*}{6} & Luas Lahan $\left(\mathrm{m}^{2}\right)$ & & \\
\hline & a. $\leq 5.000$ & 26 & 35,13 \\
\hline & b. $5.001-10.000$ & 21 & 28,37 \\
\hline & c. $\geq 10.000$ & 27 & 36,84 \\
\hline \multirow[t]{4}{*}{7} & Status Kepemilikan Lahan & & \\
\hline & a. Milik sendiri & 64 & 86,48 \\
\hline & b. Sewa & 1 & 1,35 \\
\hline & c. Milik sendiri\&sewa & 9 & 12,16 \\
\hline
\end{tabular}


yang diberikan untuk keluarga dari kegiatan berusahatani.

Sebagian besar responden bermata pencaharian sebagai petani, yang menunjukkan bahwa petani akan memfokuskan pekerjaan atau sumberdayanya untuk berusaha tani ubi kayu. Sementara itu jumlah responden berdasarkan luas lahan memiliki komposisi yang hampir berimbang antara berlahan sempit, sedang dan luas. Semakin luas lahan yang dimiliki, diduga petani akan semakin komersial dala mengusahakan lahannya. Dan berdasarkan status kepemilikan lahan, sebagian besar petani memiliki sendiri lahan yang digunakannya untuk berusahatani. Dengan demikian keuntungan dalam kegiatan usahatani lebih dapat dimaksimalkan.

\section{Mekanisme Penentuan Rafaksi}

Rafaksi berarti pemotongan (pengurangan) terhadap harga barang yang diserahkan karena mutunya lebih rendah daripada contohnya atau karena mengalami kerusakan dalam pengirimannya. Pada ubi kayu rafaksi diberlakukan dalam bentuk potongan (pengurangan) terhadap berat ubi kayu petani yang dijual kepada pembeli. Misalkan petani menjual hasil panen sebanyak $7.260 \mathrm{~kg}$, lalu pabrik menetapkan rafaksi sebesar 14 persen, sehingga berat yang dibayarkan oleh pabrik hanya sebanyak 6.240 kg ubi kayu dan sisanya sebanyak $1.020 \mathrm{~kg}$ dianggap sebagai rafraksi. Beberapa komoditas pertanian, istilah rafaksi sering digunakan untuk menilai kualitas beras, jagung, tebu dan ubi kayu. Namun penilaian kualitas yang telah memiliki acuan standarisasi dengan baik untuk rafaksi hanya terdapat pada komoditas beras yang tertuang dalam tabel rafaksi harga pembelian gabah dan beras yang dikeluarkan oleh Kemeterian Pertanian. Sementara untuk komoditas yang lainnya belum ada aturan standar yang tepat untuk pengukuran kualitas komoditas-komoditas tersebut, termasuk ubi kayu.

Selama ini penentuan rafaksi lebih didominasi oleh keputusan pabrik dan pedagang dengan melihat varietas, usia panen, kadar aci dan kotoran atau materi lain yang terbawa pada saat panen yang sangat sedikit adanya keterbukaan dalam penetapannya. Cara penentuan rafaksi bagi petani menjadi sesuatu yang dirahasiakan oleh pabrik atau pedagang dan tidak bisa diprediksikan oleh petani serta terkesan sangat subyektif. Penentuan rafaksi seharusnya menjadi kesepakatan kedua belah pihak, dan kedua belah pihak memiliki pengatahuan yang sama tentang cara penentuannya.

Perbedaan persepsi terhadap kualitas ubi kayu dalam proses jual beli ubi kayu menyebabkan pendataan mengenai kualitas ubi kayu yang ditransaksikan menjadi sulit. Petani ubi kayu tidak memiliki pengetahuan yang baik mengenai bagaimana penentuan rafaksi oleh pabrik atau pedagang. Antara petani, pedagang dan pabrik juga memiliki persepsi yang berbeda dalam menilai kualitas ubi kayu. Kriteria yang menjadi nilai kualitas ubi kayu terkadang tidak bisa dijelaskan secara terukur oleh pabrik, pedagang, maupun petani, dan hanya diperoleh kriteria yang pasti yaitu dalam hal varietas dan usia panen. Sementara itu untuk kriteria kotoran dan materi lain yang terbawa saat panen, seperti bonggol, 
Tabel 2. Kriteria Penentuan Kualitas Ubi kayu secara Visual Berdasarkan Persepsi Petani

\begin{tabular}{lll}
\hline No & Kriteria & Derajat Kualitas \\
\hline 1 & Usia panen & $>8$ bulan \\
2 & Varietas & Casesart \\
3 & Bonggol atau batang & Terpotong rapi \\
4 & Tanah atau kotoran & Sedikit \\
\hline
\end{tabular}

tidak diperoleh alat ukur untuk mengukurnya dan hanya menggunakan pengamatan dengan menggunakan penglihatan (secara visual). Kriteria kadar aci diklaim diukur melalui alat yang dimiliki oleh pabrik, namun bagaimana pengukuran dan cara mengetesnya tidak pernah diketahui oleh petani. Sementara pedagang tidak memiliki kemampuan dalam mengukur kriteria kadar aci. Pada level pabrik beberapa sumber menyebutkan adanya penambahan penilaian kualitas ubi kayu yaitu diameter ubi kayu dan kadar kelayuan atau kebusukan. Hasil kajian menunjukkan kriteria visual yang digunakan untuk menentukan kualitas (Tabel 2).

Baik petani, pedagang dan pabrik hanya memiliki kesamaan dalam pengukuran kualitas usia panen yaitu ubi kayu berusia diatas 8 bulan. Begitu juga dengan varietas ubi kayu. Petani, pedagang dan pabrik memiliki persamaan pengetahuan bahwa varietas casesart dinilai memiliki kadar aci yang lebih tinggi dibandingkan ubi kayu varietas lain seperti BW atau Adira. Sementara untuk kotoran dan bonggol, baik petani, pedagang dan pabrik memiliki persepsi yang berbeda-beda dalam menafsirkan kriteria "banyak”, “sedang” ataupun “sedikit” nya. Bahkan bila panen ubi kayu dilakukan di musim kemarau nilai rafaksi bisa turun karena kotoran pada ubi kayu dianggap lebih sedikit, dan sebaliknya pada musim hujan rafaksi bisa naik karena dianggap kotoran pada ubi kayu lebih banyak.

Hasil pengujian secara statistik mengenai hubungan antara usia panen dan rafaksi. Diperoleh nilai r (korelasi) sebesar 0,186 dan tanda pada nilai $\mathrm{r}$ menunjukkan negatif, serta tidak diperoleh hasil secara nyata (Tabel 3). Nilai ini berarti bahwa hubungan antara usia panen dan rafaksi sangat lemah karena nilai r kurang dari 0,200 (Pratisto, 2009). Koefisien korelasi bertanda negatif (-) yang berarti terdapat hubungan negatif antara usia panen dan rafaksi, yaitu semakin tinggi usia maka rafaksi akan semakin kecil dan sebaliknya. Namun nilai peluang pada hasil pengujian ini sebesar 0,138 yang berarti tidak signifikan. Hubungan antara varietas ubi kayu dan rafaksi diperoleh nilai $r$

Tabel 3. Korelasi Antara Rafaksi dengan Usia Panen dan Rafaksi dengan Varietas

\begin{tabular}{llcc}
\hline & & Usia & Varietas \\
\hline Rafaksi & Pearson correlation & -0.186 & -0.073 \\
& P value & 0.138 & 0.565 \\
\hline
\end{tabular}


(korelasi) sebesar 0,073 dan tanda pada nilai $\mathrm{r}$ menunjukkan negatif, serta hasil pengujian yang tidak nyata. Nilai r pada hasil pengujian berarti bahwa hubungan antara varietas dan rafaksi adalah sangat lemah, karena nilai $\mathrm{r}$ kurang dari 0,200. Koefisien korelasi bertanda negatif (-) yang berarti terdapat hubungan negatif antara varietas ubi kayu dan rafaksi, yaitu rafaksi akan semakin kecil apabila varietas ubi kayu yang dijual petani adalah jenis casesart dan semakin besar bila varietas ubi kayu yang dijual petani bukan casesart. Varietas ubi kayu dinyatakan dengan dummy, dimana dummy $=1$ adalah varietas ubi kayu casesart, dan dummy $=0$ adalah varietas ubi kayu selain casesart. Hasil ini menegaskan bahwa hubungan antara varietas dan rafaksi tidak diperoleh hasil secara nyata.

Adanya perbedaan kualitas dan kriterianya berdasarkan persepsi petani, pedagang maupun pabrik, menunjukkan adanya informasi yang asimetris antara ketiganya dan cenderung merugikan petani dalam bertransaksi. Keterbatasan informasi yang dimiliki petani mengenai penentuan rafaksi menyebabkan rasionalitas petani menjadi terbatas (bounded rationality) dan pasrah menghadapi lingkungan pemasaran ubi kayu yang demikian. Meminjam istilah Hayami dan Kikuchi (1981) dalam Sisfahyuni (2011) kepasrahan tersebut masih dalam lingkup rasionalitas (yang terbatas), rasional ala petani.

Selama ini hanya sedikit petani yang bisa melakukan upaya negoisasi terkait dengan penentuan rafaksi terutama petani dengan luas lahan dan hasi panen besar.
Petani dengan luas lahan dan hasil panen besar bisa melakukan tawar menawar dengan pabrik terkait jumlah rafaksi yang akan diberikan pabrik pada hasil panen mereka, namun hal ini tidak berlaku pada petani dengan luas lahan dan hasil panen kecil. Hal ini semakin menunjukkan bahwa penentuan rafaksi sangat subyektif dan tidak bergantung pada kondisi obyektif sesuai kualitas ubi kayu petani. Apabila kondisi praktik pasar yang tidak transparan ini terus berlangsung, dan tidak ada tindak lanjut dari pemerintah, maka dikhawatirkan dikemudian hari petani ubi kayu akan beralih pada komoditas lain yang dianggap lebih menguntungkan dan mengancam ketersediaan ubi kayu di dalam negeri hingga ketergantungan pada impor lebih tinggi.

\section{Harga Ubi Kayu yang Diterima Petani Setelah Adanya Rafaksi}

Harga ubi kayu di Lampung tidak menjadi satu-satunya sinyal keuntungan bagi petani, tetapi juga rafaksi. Ketika harga tinggi tetapi rafaksi yang diperoleh juga tinggi, maka petani akan merasa dirugikan, terlebih lagi pada saat harga rendah. Perhitungan mengenai harga ubi kayu yang diterima oleh petani sangat penting guna mengetahui harga ubi kayu yang sebenarnya, bukan harga yang dijanjikan oleh pabrik atau pedagang sebelum mereka memberikan rafaksi pada hasil panen yang dijual petani. Petani ubi kayu di Kabupaten Lampung Tengah menjual ubi kayu melalui beberapa saluran pemasaran yang menawarkan harga yang berbeda-beda juga. Setelah dilakukan perhitungan terhadap harga ubi kayu yang diterima 
Tabel 4. Harga yang Diterima Petani Setelah Adanya Rafaksi

\begin{tabular}{lll}
\hline Lembaga pemasaran & Harga yang dijanjikan & Harga yang diterima \\
\hline Pabrik & 1.097 & 947 \\
Lapak & 1.018 & 843 \\
Pemborong & 900 & 900 \\
Supir truk & 1.008 & 837 \\
Mitra & 973 & 861 \\
\hline
\end{tabular}

petani, maka diperolehlah harga sebenarnya seperti yang tercantum pada Tabel 4.

Dari tabel 4 diperoleh harga yang diterima oleh petani dibawah dari harga yang dijanjikan oleh pembeli akibat adanya rafaksi. Hal ini menunjukkan bahwa adanya rafaksi memberikan pengurangan terhadap harga yang dijanjikan. Sehingga harga yang diterima petani ini seharusnya yang menjadi harga yang sebenarnya untuk menjadi informasi pasar mengenai harga ubi kayu di Kabupaten Lampung Tengah. Harga yang diterima petani ini akan menggambarkan keuntungan petani ubi kayu yang sesungguhnya, bahwa ternyata harga ubi kayu masih di bawah Rp 1.000/kg sehingga keuntungan yang diterima juga relatif kecil. Meskipun petani tidak melakukan perhitungan ini, namun petani dapat merasakan bahwa adanya rafaksi membuat keuntungan berkurang dibandingkan dengan keuntungan yang diharapkan ketika menaruh ekspektasi pada harga yang dijanjikan oleh pembeli sebelum ada rafaksi. Hal ini kemudian diduga membuat petani enggan untuk meningkatkan produktivitas ubi kayunya mengingat penentuan rafaksi ubi kayu oleh pembeli juga tidak dilakukan dengan benar, bahkan dapat menjadi penyebab petani untuk beralih pada komoditas lain yang dinggap lebih menguntungkan.

\section{Pengaruh Rafaksi pada Pilihan Saluran Pemasaran}

Rafaksi menjadi salah satu hal yang mempengaruhi petani dalam memilih saluran pemasaran hasil panennya. Informasi rafaksi yang diperoleh petani lain dalam menjual ubi kayu pada suatu lembaga pemasaran menjadi sinyal bagi petani untuk memilih saluran pemasaran meskipun petani belum mengetahui berapa rafaksi yang akan diperolehnya saat menjual ubi kayu nanti. Dengan demikian risiko ketidak-pastian masih dihadapi petani sebelum menjual ubi kayu karena nilai rafaksi yang diperoleh diketahui setelah menjual ubi kayu. Namun demikian infornasi rafaksi di awal sebelum menjual ubi kayu yang diperoleh petani dari petani lain atau pedagang mampu membuat petani mempertimbangkan kemana ubi kayu yang dimilikinya akan dijual.

Dalam menjual hasil panennya, petani ubi kayu di Kabupaten Lampung Tengah memiliki empat lembaga pemasaran sebagai alternatif dalam menyalurkan produknya, yaitu pabrik, lapak, pemborong, supir truk dan mitra. Pada penelitian ini pilihan lembaga pemasaran hanya dibedakan menjadi dua, 
yaitu pabrik dan selain pabrik. Hal ini untuk membedakan perilaku lembaga pemasaran yang melakukan fungsi utamanya dalam kegiatan fungsi pengolahan ubi kayu (pabrik) dan fungsi jual beli (lapak, pemborong, supir truk dan mitra). Hasil analisis regresi logistik biner mengenai faktor-faktor yang mempengaruhi pilihan saluran pemasaran petani ubi kayu di Kabupaten Lampung Tengah ditunjukkan pada tabel 5 .

Petani ubi kayu di Kabupaten Lampung Tengah dalam memilih saluran pemasaran, diduga dipengaruhi oleh faktor-faktor seperti harga, jumlah hasil panen, jarak, usia panen, tingkat pendidikan, rafaksi atau potongan berat sampai adanya pinjaman modal yang diberikan oleh lembaga saluran pemasaran. Hasil pendugaan koefisien model regresi logistik faktor-faktor yang mempengaruhi pilihan saluran pemasaran petani ubi kayu di Kabupaten Lampung Tengah didapatkan bahwa variabel harga, jumlah panen, rafaksi dan adanya pinjaman modal mempengaruhi pemilihan saluran pemasaran secara signifikan pada taraf nyata hingga 10 persen. Sedangkan lama jarak, pendidikan dan usia panen tidak signifikan dalam mempengaruhi pilihan saluran pemasaran yang dilakukan oleh petani ubi kayu di Kabupaten Lampung Tengah. Model yang dihasilkan memiliki $R$-square sebesar 73,2 persen yang ditunjukkan oleh nilai Negalkerke $\mathrm{R}$ square, yang tergolong cukup tinggi untuk data cross section. Angka ini berarti, sebesar 73,2 persen keragaman data tujuan pilihan saluran pemasaran ubi kayu dapat dijelaskan oleh faktor-faktor yang mempengaruhi petani ubi kayu, sedangkan sisanya dipengaruhi oleh halhal yang tidak dijelaskan oleh model.

Variabel rafaksi memiliki nilai koefisien bertanda positif dan odds ratio sebesar 8.742,012. Nilai ini bermakna bahwa setiap kenaikan atau perbedaan satu persen rafaksi, maka peluang petani untuk memilih tujuan penjualan ke pabrik lebih besar 8.742,012 kalinya dari peluang untuk memilih tujuan penjualan

Tabel 5. Uji Wald (Parsial) Faktor-Faktor yang Berpengaruh pada Pilihan Saluran Pemasaran

\begin{tabular}{lccr}
\hline \multicolumn{1}{c}{ Variabel } & $\begin{array}{c}\text { Parameter } \\
\text { Dugaan }\end{array}$ & P value & $\begin{array}{c}\text { Exp (B) atau } \\
\text { Odds Ratio }\end{array}$ \\
\hline Rafaksi & $9.076^{*}$ & .089 & 8742.012 \\
Harga & $.012^{* *}$ & .010 & 1.012 \\
Jumlah Panen & $.000^{*}$ & .040 & 1.000 \\
Jarak & .238 & .119 & 1.268 \\
Pendidikan & .086 & .584 & 1.089 \\
Usia & -.031 & .921 & 0.970 \\
Pinjaman modal & $-22.670^{*}$ & .069 & 0.000 \\
(1=ada 0=tidak ada) & & & 0.000 \\
Intersep & -16.052 & .010 & 0.732 \\
\hline Negalkerke R square & & &
\end{tabular}


ubi kayu ke lembaga selain pabrik. Peluang ini sangat besar bila dibandingkan dengan peluang pada variabel lain, yang berarti rafaksi sangat berperan penting dalam mempengaruhi pilihan saluran pemasaran petani.

Nilai rafaksi yang semakin tinggi akan membuat petani lebih memilih untuk menyalurkan produknya pabrik dibandingkan dengan lembaga pemasaran selain pabrik. Kondisi ini dimungkinkan karena lembaga lain selain pabrik (dalam hal ini lapak) tidak memberikan alternatif rafaksi yang lebih baik dalam artian lebih rendah nilai rafaksinya. Tingkat rafaksi yang tinggi di level pabrik justru akan diikuti dengan rafaksi yang lebih tinggi lagi di level pedagang karena pedagang merupakan bagian perpanjangan tangan dari pabrik.

Menjual ubi kayu ke pabrik lebih menguntungkan menurut petani karena lebih memberikan kepastian dalam hal penentuan rafaksi yang lebih baik. Mengingat pada level pedagang, akurasi pengukuran rafaksi lebih meragukan dibandingkan dengan penentuan rafaksi oleh pabrik. Meskipun selama ini mekanisme penentuan rafaksi tidak dapat ditentukan secara pasti dan pembeli memiliki power yang lebih kuat dalam menentukan rafaksi namun petani lebih memilih untuk menjual ke pabrik.

Variabel harga memiliki nilai koefisien bertanda positif dan odds ratio sebesar 1,012. Hasil statistik ini memiliki makna bahwa setiap kenaikan atau perbedaan satu satuan harga jual ubi kayu maka peluang petani untuk memilih tujuan penjualan ubi kayu ke pabrik adalah 1,012 kalinya dari peluang untuk memilih tujuan penjualan ubi kayu ke lembaga selain pabrik. Semakin tinggi harga jual ubi kayu yang ditetapkan oleh pabrik maka petani akan cenderung untuk memilih menjual ubi kayu pada pabrik. Harga bagi sebagian petani merupakan sinyal utama untuk memilih saluran pemasaran ubi kayunya. Pabrik memberikan harga yang lebih baik jika dibandingkan dengan lembaga lain, seperti tercantum pada Tabel 4.

Pabrik tidak jarang juga memberikan harga yang dinilai rendah oleh petani terutama pada saat keadaan ubi kayu melimpah atau panen raya. Namun lembaga pemasaran yang lain juga ternyata tidak mampu memberikan alternatif harga yang lebih baik dari pabrik mengingat terkadang mereka juga merupakan bagian perpanjangan tangan dari pabrik. Hal ini membuat petani merasa dirugikan. Sebaliknya pada saat stok ubi kayu berkurang dan hanya sedikit petani yang panen ubi kayu maka pabrik akan menaikkan harga ubi kayu. Bahkan bisa juga diikuti dengan perang harga dan rafaksi antar pabrik ubi kayu, sehingga mampu menarik petani untuk menjual ubi kayu ke pabriknya. Kemampuan pabrik untuk mengontrol harga dan rafaksi terjadi mengingat struktur pasar ubi kayu di Lampung Tengah yang tidak efisien dengan struktur yang cenderung oligopsoni dengan monopsony power yang lemah.

Lembaga pemasaran yang berupa agen seperti supir truk dan mitra tidak memberikan perbedaan dalam harga, artinya petani mendapatkan harga pada kedua lembaga ini sama sesuai dengan harga pabrik dimana agen tersebut 
menjualkan ubi kayu petani. Menjual melalui agen memiliki arti bahwa agen tersebutlah yang memilihkan kemana ubi kayu tersebut akan dijual dan petani mengikuti keputusan agen. Ini artinya keputusan mengenai harga yang diterima ada di tangan agen. supir truk dan mitra. Hubungan antara petani dan agen ini menurut Salvatore (2007) merupakan suatu hubungan agensi principal agent. Petani sebagai pemilik produk disebut sebagai principal, dan agen yang menjualkan produk kepada pembeli disebut sebagai agent, dimana agen menyelenggarakan beberapa jasa dengan pendelegasian wewenang pengambilan keputusan telah diberikan principal kepada agen.

Sebanyak 29,73 persen atau 22 responden petani ubi kayu di Kabupaten Lampung Tengah terlibat dalam kelembagaan principal agent. Suatu permasalahan principal agent muncul ketika para agen mencari cara untuk memaksimalkan keuntungan mereka sendiri dibandingkan keinginan petani sebagai pemilik produk atau principal (Malmir et al, 2014). Kenyataannya, agen supir truk atau mitra tidak jarang bertindak opportunis dimana dia akan berusaha memaksimalkan keuntungan yang diperolehnya dengan menyetorkan ubi kayu di pabrik tempatnya melakukan kerjasama dan mengesampingkan kepentingan petani untuk memperoleh harga yang paling baik. Di sisi lain, menjual melalui agen yang berupa mitra atau supir truk akan membuat petani mendapatkan bagi hasil atas fee yang diberikan pabrik kepada agen sebesar Rp 10/kg. Fee merupakan bagian dari aturan main (kontrak) dalam kelembagaan principal agent antara petani dengan supir truk atau mitra.

Variabel ketiga yaitu jumlah hasil panen memiliki nilai koefisien bertanda positif dan odds ratio sebesar 1,000. Nilai ini bermakna bahwa setiap kenaikan atau perbedaan satu kilogram kuantitas hasil panen petani, maka peluang untuk memilih tujuan penjualan hasil panen ke pabrik lebih besar 1,000 kalinya dari peluang untuk memilih tujuan penjualan ubi kayu ke lembaga selain pabrik atau bisa dikatakan peluang antara ke pabrik dengan ke selain parik adalah sama. Jumlah hasil panen juga memiliki keterkaitan dengan rafaksi. Dalam jumlah besar, petani dapat melakukan tawar menawar mengenai rafaksi yang akan dikenakan pada hasil panen ubi kayunya. Sementara petani yang memiliki jumlah panen sedikit tidak bisa mempengaruhi rafaksi dengan cara tawar menawar. Oleh karena itu hasil panen membuat lembaga pemasaran menjadi lebih fleksibel dan hal ini cenderung merugikan petani yang memiliki jumlah hasil panen sedikit.

Variabel yang terakhir yaitu pinjaman modal memiliki nilai koefisien bertanda negatif dan odds ratio sebesar 0,0001. Nilai ini bermakna bahwa peluang petani yang ada pinjaman modal untuk memilih menjual hasil panen ke pabrik adalah 0,0001 lebih kecil dari peluang petani yang tidak ada pinjaman modal. Ketika petani menginginkan pinjaman modal, maka ia harus memilih untuk menjual ubi kayu melalui lembaga pemasaran selain pabrik, yaitu mitra.

Dalam rangka mendapatkan modal inilah petani terlibat kelembagaan agent 
principal dengan mitra, yang memiliki keterikatan kontrak sangat kuat meskipun tidak dilakukan perjanjian tertulis. Kesepakatan-kesepakatan yang terjadi antara petani dan mitra hanya atas dasar kepercayaan. Petani yang mendapatkan modal dari mitra maka secara otomatis saat panen harus menjual ubi kayunya melalui mitra. Modal yang diberikan oleh mitra bisa berupa uang, pupuk, bibit dan obat-obatan yang memiliki perbedaan harga rata-rata Rp 20.000 per sak pupuk atau botol obat dibandingkan dengan harga normal dipasaran. Dengan demikian meminjam modal melalui mitra menyebabkan berkurangnya keuntungan yang diterima petani nantinya.

\section{Simpulan}

\section{SIMPULAN DAN SARAN}

1. Penentuan rafaksi ubi kayu ditentukan melalui beberapa kriteria seperti usia panen, varietas, kadar aci dan banyaknya kotoran namun tidak diperoleh alat ukur untuk memastikan kriteria tersebut saat transaksi, dan hanya menggunakan pengamatan secara visual. Pembeli memiliki power lebih kuat dalam menentukan kualitas ubi kayu yang diperjual belikan dan cenderung merugikan petani karena penentuan rafaksi terkesan subyektif. Hasil analisis korelasi menunjukkan tidak terdapat hubungan yang nyata antara usia panen dan varietas ubi kayu dengan rafaksi ubi kayu yang diterima petani.

2. Harga yang diterima petani ubi kayu setelah adanya rafaksi lebih rendah dibandingkan dengan harga sebelum adanya rafaksi.
3. Rafaksi memiliki pengaruh nyata terhadap pilihan saluran pemasaran petani ubi kayu dan memiliki nilai peluang paling tinggi dibandingkan dengan variabel-variabel lainnya. Saluran pemasaran pabrik memberikan nilai rafaksi yang lebih baik menurut petani dibandingkan dengan saluran pemasaran lainnya meskipun semuanya berada pada kondisi ketidakpastian didalam menentukan rafaksi ubi kayu.

\section{Saran}

1. Pembeli (pabrik dan lapak) diharapkan lebih transparan dalam penentuan rafaksi ubi kayu petani agar potongan berat sesuai dengan kondisi obyektif ubi kayu. Perlu dibenahi sistem pengukuran yang hanya berdasarkan pengamatan secara visual agar menggunakan alat yang lebih terukur dan sesuai dengan kondisi obyektif ubi kayu petani.

2. Peran pemerintah dibutuhkan untuk mengatur regulasi mengenai bagaimana penentuan rafaksi ubi kayu sehingga membuat pasar lebih adil bagi petani ubi kayu.

3. Antara pabrik dan petani diharapkan dapat terjalin suatu hubungan kemitraan untuk menjamin kepastian pemasaran ubi kayu bagi petani dan menghindari anjloknya harga yang sering terjadi saat panen raya.

\section{DAFTAR PUSTAKA}

Akiyama, Takamasa dan Akihiko Nishio. 1996. Indonesia's Cocoa Boom Hands-off Policy Encourages Smallholder Dynamism. Policy 
Research Working Paper. The World Bank : International Economics Department Commodity Policy and Analysis Unit and Country Department II.

[BPS] Badan Pusat Statistik. 2016. Luas panen, produksi, dan produktivitas ubi kayu di Indonesia tahun 20092015. [internet]. [diunduh 2016 Jan 1]. Tersedia pada :

http://www.bps.go.id/linktTableDinamis/ view/id/880

Chirwa, EW. 2009. Determinants of Marketing Channels among Smallholder Maize Farmers in Malawi. Working Paper. No 2009/03. Malawi : University of Malawi.

[FAO] Food and Agriculture Organization. Harvested area, production and productivity of cassava. [internet]. [diunduh 2016 Jan 1]. Tersedia pada :

http://faostat3.fao.org/download/Q/QC/E

Kementerian Pertanian. Ekspor Impor Komoditi Pertanian Per Sub Sektor tahun 2009 s.d 2015. [internet]. [diunduh 2016 Jan 1]. Tersedia pada

http://aplikasi.deptan.go.id/eksim2 012/imporSubsek.asp

Kotler P. 1997. Manajemen Pemasaran: Analisis, Perencanaan, Implementasi dan Pengendalian. Edisi ketujuh. Jakarta (ID): Fakultas Ekonomi UI.

Kotler P, Keller KL. 2009. Manajemen Pemasaran Edisi ke 13. Jakarta (ID : Erlangga.
Malmir, Ameneh, Alireza Shirvani, Ali Rashidpour and Iraj Soltani. 2014. Citizen Relationship Management and Principal/Agent Theory. International Journal of Managing Value and Supply Chains (IJMVSC). 5 (3) : 83 - 90.

Pratisto, Arif. 2009. Statistik Menjadi Mudah dengan SPSS 17. Jakarta (ID) :PT Elex Media Komputindo.

Sagala, Elizabet. 2011. Manajemen Panen dan Pascapanen Ubi Kayu (Manihot esculenta Crantz) di PT Pematang Agri Lestari untuk Bahan Baku Industi Tapioka PT Sinar Pematang Mulia I [skripsi]. Bogor : Institut Pertanian Bogor.

Saliem, HP dan Sri Nuryanti. 2011. Perspektif Ekonomi Global Kedelai dan Ubi Kayu Mendukung Swasembada. Analisis Kebijakan Pertanian. Jakarta : Pusat Sosial Ekonomi dan Kebijakan Pertanian.

Salvatore, Dominick. 2007. Mikroekonomi. Jakarta (ID): Erlangga.

Sisfahyuni, MS Saleh, dan MR Yantu. 2011. Kelembagaan Pemasaran Kakao Biji di Tingkat Petani Kabupaten Parigi Moutong Provinsi Sulawesi Tengah. Jurnal Agro Ekonomi. 29 (2) : 191 - 216.

Sugino, Tomohide dan Henny Mayrowani. 2009. The Determinants of Cassava Productivity and Price Under The Farmers' Collaboration with The Emerging Cassava Processors: A Case Study in East Lampung, Indonesia. Journal of Development and Agricultural Economics. 1(5) : 114-120. 
Zakaria, WA. 2000. Analisis Penawaran dan Permintaan produk Ubi Kayu Lampung serta Kaitannya dengan Pasar Domestik dan Dunia [disertasi]. Bogor : Institut Pertanian Bogor. 
Lampiran 1. Hasil Estimasi Fungsi Regresi Logistik Faktor-faktor yang Mempengaruhi Pilihan Saluran Pemasaran Petani Ubi Kayu di Kabupaten Lampung Tengah

\begin{tabular}{|c|c|c|c|c|c|c|c|}
\hline & \multirow[t]{3}{*}{ B } & & & & & \\
\hline & & & \multirow[t]{2}{*}{ Bias } & \multirow[t]{2}{*}{ Std. Error } & \multirow[t]{2}{*}{$\begin{array}{l}\text { Sig. (2- } \\
\text { tailed) }\end{array}$} & \multicolumn{2}{|c|}{$\begin{array}{l}\text { 95\% Confidence } \\
\text { Interval }\end{array}$} \\
\hline & & & & & & Lower & Upper \\
\hline \multirow{8}{*}{ Step 1} & Harga & .012 & .034 & .154 & .010 & .005 & .663 \\
\hline & Panen & .000 & .000 & .002 & .040 & .000 & .006 \\
\hline & Jarak & .238 & .317 & 1.958 & .119 & -.584 & 5.158 \\
\hline & Pendidikan & .086 & .828 & 3.798 & .584 & -.354 & 18.904 \\
\hline & Pinjaman & -22.670 & -5.095 & 17.784 & .069 & -90.607 & -19.919 \\
\hline & Rafaksi & 9.076 & 8.602 & 52.613 & .089 & -17.927 & 240.757 \\
\hline & Usia & -.031 & -1.005 & 7.754 & .921 & -13.614 & 1.412 \\
\hline & Constant & -16.052 & -41.286 & 172.180 & .010 & -745.351 & -8.575 \\
\hline
\end{tabular}

Hosmer and Lemeshow Test

\begin{tabular}{|l|r|r|r|}
\hline Step & Chi-square & df & \multicolumn{1}{c|}{ Sig. } \\
\hline 1 & 8.535 & 8 & .383 \\
\hline
\end{tabular}

Model Summary

\begin{tabular}{|l|r|r|r|}
\hline Step & $\begin{array}{c}-2 \text { Log } \\
\text { likelihood }\end{array}$ & $\begin{array}{c}\text { Cox \& Snell R } \\
\text { Square }\end{array}$ & $\begin{array}{c}\text { Nagelkerke R } \\
\text { Square }\end{array}$ \\
\hline 1 & $43.330^{\mathrm{a}}$ & .548 & .732 \\
\hline
\end{tabular}

Omnibus Tests of Model Coefficients

\begin{tabular}{|rl|r|r|r|}
\hline & & Chi-square & \multicolumn{1}{c|}{ df } & \multicolumn{1}{c|}{ Sig. } \\
\hline \multirow{3}{*}{ Step 1 } & Step & 58.768 & 7 & .000 \\
& Block & 58.768 & 7 & .000 \\
& Model & 58.768 & 7 & .000 \\
\hline
\end{tabular}

